\title{
合成コムIIRの試験方法
}

\section{Testing Methods for Synthetic Rubber IIR}

1. 適用範囲 この規格は，合成ゴム IIR（イソブチレン・イソプレン系合成ゴム，以下 IIR という.) の試験方法について規定する．ただし，八ロゲン化 IIR 及びラテックスは除く.

備考 この規格の中で \} を付けて示してある単位及び数值は国際単位系 (SI) であって, 参考として併記したも のである.

2. 試験項目及び求める試験成績のけた数 試験項目及び求める試験成績のけた数は, 表 1 のとおりと し，試験成績のけた数は JIS Z 8401 （数值の丸め方）によって丸める.

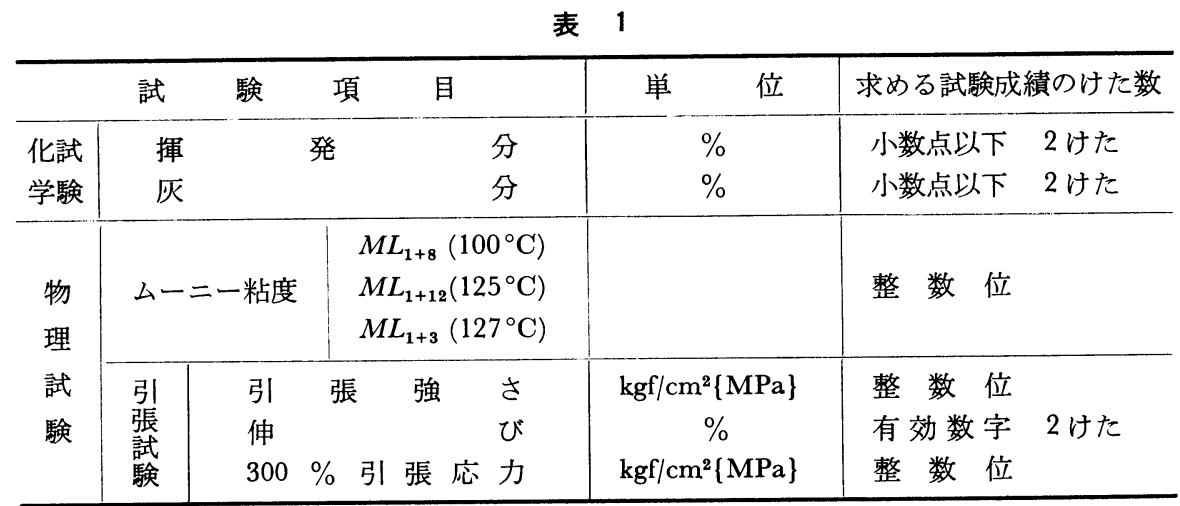

3. 試料採取方法 試料は，品質が同一とみなすことのできるロット及びその端数ごとに試料を採取 し，その表面に付着した異物を除去し気密が保てる容器に保管して試験に供する．ただし，試料を採る ための供試品のロットの決め方及び採取数は当事者間の協定による.

4. 化学試験方法

4.1 揮 発 分 試料約 $10 \mathrm{~g}$ を約 $1.5 \mathrm{~mm}$ 角程度に細かく切り, あらかじめ恒量にした深さ $15 \mathrm{~mm}$, 直径 $60 \mathrm{~mm}$ のアルミニウム試料ざらに入れ $\left(^{1}\right), 1 \mathrm{mg}$ まで正しく量る. これを $105 \pm 11^{\circ} \mathrm{C}$ 保った空気循 環式乾燥器中に入れて，1時間加熱乾燥した後取り出し，デシケータ中で放泠し，再び量り，次の式に よって揮発分を算出する. 試験は 2 回行い, その平均值を求める.

$$
\begin{array}{cl}
V_{0}= & \frac{S-B_{0}}{S} \times 100 \\
\text { ここに } \quad V_{0}: \text { 揮発分 }(\%) \\
S: \text { 試料の質量 }(\mathrm{g}) \\
B_{0}: \text { 乾燥後の試料の質量 }(\mathrm{g})
\end{array}
$$

注( $\left.{ }^{1}\right)$ 試料をアルミニウム試料ざらに入れる場合, ゴムが互いに密着しないよらに入れる.

4.2 灰分 4.1で乾燥した試料を細かく切り, 質量を量ってある磁器るつぼ $50 \mathrm{~m} l$ に試料約 $3 \mathrm{~g}$ を $0.1 \mathrm{mg}$ まで正しく量り採る。試料はできるだけるつぼの底のほうに入れる．るつぼを $550 \pm 25^{\circ} \mathrm{C} に$ 保 ったマッフル炉に入れ恒量になるまで灰化する $\left(^{2}\right)$.この場合, 炉に入れてから 1 時間以内に炉の戸を開 いてはならない，完全に燃焼した後，るつぼを取り出してデシケータ中で室温まで放冷し残分の質量を 
量り，次の式によって灰分を算出する. 試験は 2 回行い，その平均值を求める.

$$
\begin{gathered}
A=\frac{W_{A}}{S} \times 100 \\
\text { ここ } A: \text { 灰 分 }(\%) \\
S: \text { 試料の質量 }(\mathrm{g}) \\
W_{A}: \text { 残分の質量 }(\mathrm{g})
\end{gathered}
$$

注 $\left.{ }^{2}\right)$ るつぼの中の灰の上縁が，るつぼの上縁から $2 \mathrm{~mm}$ 以内に付着していたら，試料を新しく採って再測 定を行わなければならない.ゴムが灰化過程でるつぼからあふれるおそれのある場合には，灰化前に径 $150 \mathrm{~mm}$ の定量分析用ろ紙で試料を巻き込むとよい.

\section{5. 物理試験方法}

5.1 ムーニー粘度 試料はベールから切り採りロール通しを行なわない. 試験片の大きさは,ダイス のキャビティに適合するように厚さ約 $6 \mathrm{~mm}$ ，質量約 $30 \mathrm{~g}$ とする.

JIS K 6300 (未加硫ゴム物理試験方法) の 4 亿準じてムーニー粘度を測定する．ただし，測定条件を $M L_{1+8}\left(100^{\circ} \mathrm{C}\right), M L_{1+12}\left(125^{\circ} \mathrm{C}\right), M L_{1+3}\left(127^{\circ} \mathrm{C}\right)$ のいずれにするかは当事者間の協定による.

5.2 引張試験 付属書の方法に基づいて作製した引張試験用加硫ゴム板を用いて JIS K 6301 （加硫 ゴム物理試験方法）の 3 に規定する方法によって引張強さ，伸び及び $300 \%$ 引張応力を測定する.

\section{付属書引張試験用加硫コム板の作製方法}

引張試験用加硫ゴム板は，次の標準配合及び方法によって作製する.

\begin{tabular}{|c|c|}
\hline 原 料 ゴム 及び配 合 剤 & 配合割合（質量部） \\
\hline IIR & 100.0 \\
\hline 酸 化 垔 鉛( ${ }^{(1)}$ & 3.0 \\
\hline 硫黄( $\left.{ }^{2}\right)$ & 1.75 \\
\hline ステアリン酸( $\left.{ }^{3}\right)$ & 1.0 \\
\hline カーボンブラック $(\mathrm{HAF})\left(^{4}\right)$ & 50.0 \\
\hline 加硫促進剤 TMTD( $\left.{ }^{5}\right)$ & 1.00 \\
\hline 総 質 量 部 & 156.75 \\
\hline
\end{tabular}

1. 標準配合 付属書表 1 による.ただし，配合剤の銘柄は，試験成績にこれを記録しなければならな い.

付属書 表 1

注 $\left.{ }^{1}\right)$ 酸化亜鉛は，酸化亜鉛 $99.5 \%$ 以上，鉛 $0.03 \%$ 以下，カドミウムを検出しないもので，加熱減量 $0.3 \%$ 以下，強熱減量 $0.3 \%$ 以下，水可溶分 $0.1 \%$ 以下，子るい残分 $149 \mu \mathrm{m}$ 全通， $44 \mu \mathrm{m} 0.1 \%$ 以下のものを 用いる。

(2) JIS K 6222 （ゴム用粉末硫黄）の 1 号を用いる. 
$\left(^{3}\right)$ ステアリン酸は，中和価195以上，けん化価195以上，上5素価 4 以下，加熱減量 $0.5 \%$ 以下，灰分 0.01 \%以下，融点 $55^{\circ} \mathrm{C}$ 以上のものを用いる.

(4) カーボンブラックは, NBS 378 又はこれに相当するものを乾燥して用いる. 乾燥に用いる容器は, カ 一ボンブラックの層の厚さが乾燥中 $10 \mathrm{~mm}$ 以下になるよ5な大きさのものとし, 温度 $25^{\circ} \mathrm{C}$, 相対湿度 $35 \%$ の所で 20 時間以上放置するか， $105 \pm 5{ }^{\circ} \mathrm{C}$ の炉で 1 時間加熱乾燥したものを用いる.

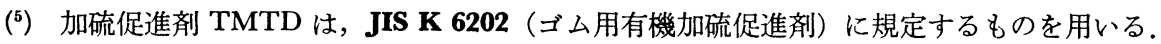

2. 混練方法 試験用練りロール機を用い，ロール表面温度を $40 \pm 5^{\circ} \mathrm{C}$ に保って次の操作方法で行う。 操作方法

(1) ロール間げきを約 $0.65 \mathrm{~mm}$ とし，ゴムをロールに巻き付ける.

(2) あらかじめ均一に混合したカーボンブラックとステアリン酸を加える。このとき，たまりのゴム が出来るようになってからロール間げきを徐々に広ろげて調整する．カーボンブラックを全部加え 終ったら $3 / 4$ 切り返し( $\left(^{6}\right)$ を左右交互に各 1 回行う.

(3) 他の配合剤を加える.

(4) 左右交互に $3 / 4$ 切り返しを各 3 回行う.

（5）練りゴムをロールから切り放し質量を量り，質量の変化が総質量部の $\pm 1 \%$ 以内にならなければ ならない。ロール間げきを $0.8 \mathrm{~mm}$ にして丸め通しを 6 回行う.

(6) 最終の厚みが $2.2 \mathrm{~mm}$ になるように加硫用ゴム板を取り出す.

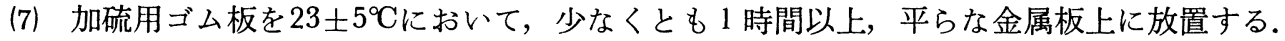
注 $\left(^{(}\right) \quad 3 / 4$ 切り返しとは，ロール幅の $3 / 4$ だけ切り込み，ロール上のたまりが見えなくなるまでナイフで切り 込みを入れておく。

3. 加硫方法 加硫プレスは，常時キャビティの面積に $35.2 \mathrm{kgf} / \mathrm{cm}^{2}\{3.5 \mathrm{MPa}\}$ 以上の圧力を加えるこ とのできるものを使用する．金型は，キャビティの梁さが $1.9 \sim 2.0 \mathrm{~mm}$ で硬質クロムめっきしたものを 用いる．加硫は， $150.0 \pm 1.5^{\circ} \mathrm{C}$ 加硫温度で 20 分，40分及び80分間行う。

金型は，未加硫生地を入れる前に加硫温度で20分間予熱しておく．離型剤は，必要がなければ金型の 表面に塗布しないほうがよい，必要な場合には，加硫試験片に影響を与えない焼付形の離型剤を用い， 余分の離型剂はゴム板を少なくとも 1 回加硫して取り除かなければならない.

加硫時間は，圧力が充分かかった瞬間から，圧力が抜けるまでの時間を指し，加硫プレスを開けたら 直ちに金型から加硫ゴム板を取り出し，水中で10 15分間冷却する. 次に布でぬぐい引張試験用加硫ゴ ム板とする.このとき不注意に取り扱って，引き伸ばしたり曲げたりしないように注意しなければなら ない.

制定 : 昭和54年 2 月 23 日

社団法人 日本ゴム協会

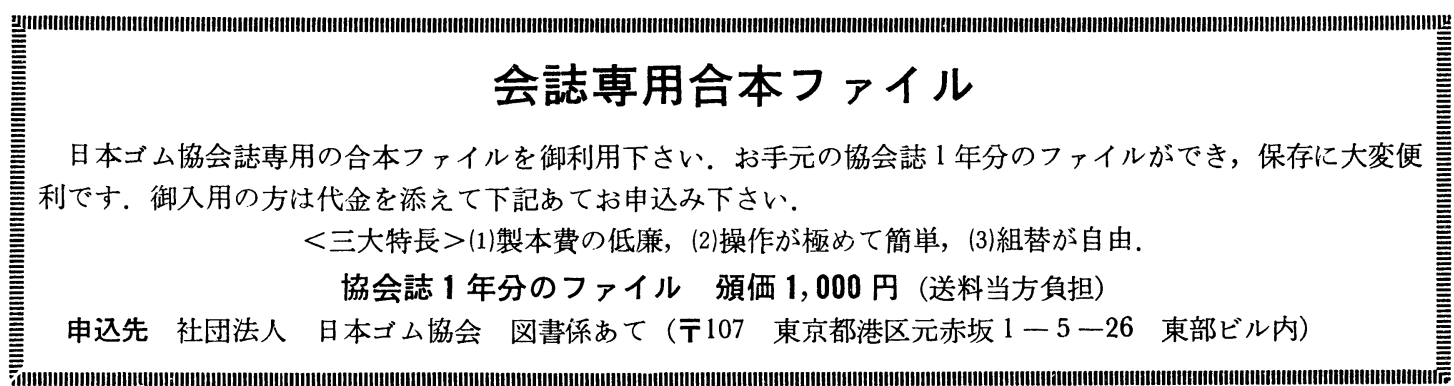

